\title{
ARTICLE \\ Suitable habitat for marine mammals during austral summer in San Jorge Gulf, Argentina
}

\author{
Distribución potencial de mamíferos marinos durante el verano austral \\ en el Golfo San Jorge, Argentina
}

\begin{abstract}
María Valeria Retana ${ }^{1 *}$ and Mirtha Noemí Lewis ${ }^{1}$
${ }^{1}$ Centro para el Estudio de Sistemas Marinos (CESIMAR-CENPAT-CONICET), Bv. Almirante Brown 2915, U9120ACD, Puerto Madryn, Argentina. *retana@cenpat-conicet.gob.ar

Resumen.- El Golfo San Jorge (GSJ) es una región oceanográfica importante debido a la influencia de dos frentes de marea, siendo uno de los sectores más productivos y con alta biodiversidad marina del Mar Argentino. El objetivo de este estudio fue identificar cuáles variables oceanográficas explican la presencia de mamíferos marinos y explorar el solapamiento de la riqueza predicha con las áreas frontales del GSJ durante el verano austral. La distribución potencial de las 9 especies (Balaenoptera sp., Cephalorhynchus commersonii, Globicephala melas, Grampus griseus, Lagenorhynchus australis, L. obscurus, Mirounga leonina, Orcinus orca, Otaria flavescens) fue modelada con Maxent utilizando 6 variables ambientales (batimetría, pendiente del fondo marino, distancia a la costa, distancia al frente de marea, temperatura superficial y concentración de clorofila). Los mamíferos marinos se encontraron más cerca de las áreas frontales que al azar (9,48 km y 13,34 km, respectivamente). La profundidad, la distancia a la costa y la pendiente fueron las variables más importantes en la distribución de todas las especies. Balaenoptera sp., G. melas, G. griseus, L. australis y 0 . orca mostraron una distribución costera $(<10 \mathrm{~km})$, principalmente al noroeste del golfo. $M$. leonina, $\mathrm{O}$. flavescens y C. commersonii siguieron la isobata de los $80 \mathrm{~m}$, mientras que $\mathrm{L}$. obscurus se distribuyó en todo el golfo. Las áreas de mayor riqueza predicha se solaparon un $75 \%$ con las áreas frontales localizadas al noroeste y sudeste del golfo. Este trabajo provee información de base para el diseño de futuros muestreos que pueden explicar la influencia de los procesos y variación estacional de la distribución de los mamíferos marinos del GSJ.
\end{abstract}

Palabras clave: Modelos de distribución, frentes de marea, mamíferos marinos, Maxent, Golfo San Jorge

\begin{abstract}
The San Jorge Gulf (SJG) is an important oceanographic region due to the influence of two tidal fronts, being one of the most productive sectors and with greater marine biodiversity in the Argentine Sea. The aim of this study was to identify which oceanographic variables best explained the presence of marine mammals and to explore the overlap of the predicted richness with the frontal areas of the SJG during the austral summer. The potential distribution of 9 species (Balaenoptera sp., Cephalorhynchus commersonii, Globicephala melas, Grampus griseus, Lagenorhynchus australis, L. obscurus, Mirounga leonina, Orcinus orca, Otaria flavescens) was modeled with Maxent using 6 environmental variables (bathymetry, seafloor slope, distance to the coast, distance to the frontal area, sea surface temperature and chlorophyll a concentration). Marine mammals were found closer to the frontal area than expected by chance $(9.48 \mathrm{~km}$ and $13.34 \mathrm{~km}$, respectively). Bathymetry, distance to the coast and seafloor slope were the most important variables in the distribution of all the species. Balaenoptera sp., G. melas, G. griseus, L. australis and O. orca showed a coastal distribution $(<10 \mathrm{~km})$, mainly in the northwest of the gulf. The distribution of $\mathrm{M}$. leonina, 0 . flavescens and $\mathrm{C}$. commersonii followed the isobaths of $80 \mathrm{~m}$, while L. obscurus evenly distributed throughout the gulf. In general, the environmental variables that influence the distribution of these species agreed with those found in previous studies from other locations. The area of high predicted richness was $75 \%$ overlapped with the frontal areas located in the northwest and southeast of the gulf. This work provides baseline information for designing future samplings that could explain the influence of the processes and the seasonal variation of the distribution of the marine mammals of the SGJ.
\end{abstract}

Key words: Distribution models, tidal fronts, marine mammals, Maxent, San Jorge Gulf

\section{INTRODUCTION}

Frontal areas are biologically productive systems with high species richness which play a major role as ecosystem boundaries, migration pathways or feeding and spawning areas for many marine organisms (Acha et al. 2004). Fronts result from several forcing factors such as tides, winds, freshwater discharges and oceanic currents that interact with geomorphological features as bathymetry (Mann \& Lazier 1996). Tidal fronts are sharp horizontal density gradients created by the turbulent mixing generated by tidal currents over shallow topography, where stratified waters, as a result of surface heating from sunlight, converge with those mixed by vertical mixing due to a strong tidal current (Simpson \& Hunter 1974). In these 
areas, the increased horizontal and vertical mixing of the water mass results in a rich primary and secondary production, with high phytoplankton biomass that favors the activity at higher trophic levels (Miller \& Christodoulou 2014). The concentration of nutrients and pelagic productivity of these areas are temporally and spatially predictable and generate 'hotspots' of biodiversity (Spear et al. 2001, Bakun 2006, Ballance et al. 2006, Sydeman et al. 2006), and marine top predators foraging in frontal regions or in areas associated to upwelling fronts are regularly observed (e.g., Tynan et al. 2005, Doniol-Valcroze et al. 2007, Gannier \& Praca 2007, Torres et al. 2008, Bost et al. 2009, Certain et al. 2011, Hazen et al. 2011, Sigler et al. 2012, Dalla Rosa et al. 2012, Benoit-Bird et al. 2013).

On the continental shelf of Argentina there are 3 tidal zones that differ in spatial and temporal scales: Southern San Jorge Gulf, Northern San Jorge Gulf and Península Valdés (Acha et al. 2004). The San Jorge Gulf (SJG) is one of the most important oceanographic regions in the continental shelf due to a high concentration of nutrients from the two coastal fronts (Acha $e t$ al. 2004, Rivas \& Pisoni 2010). These surface temperature fronts identified with satellite images are ephemeral and more intense during the austral warm spring-summer season (October-March), when the surface heat flows from the atmosphere to the ocean (Rivas 2006). In the spring-summer season, these tidal fronts separate two types of zones: one relatively cool, shallow and vertically homogeneous and the other one warm, stratified and deeper (Rivas \& Pisoni 2010). In addition, the SJG has a primary production cycle associated with the formation process of a seasonal thermocline which begins in the spring season, reaches its highest development in summer and disappears in fall (Akselman 1996). The gulf is also characterized by a high diversity of coastal and marine environments which serve as breeding grounds for different species of fish, invertebrates, seabirds and marine mammals and which also constitute feeding and resting areas for migratory birds; in this way, it becomes an important area in terms of biodiversity and productivity (Foro para la Conservación del Mar Patagónico y Áreas de Influencia 2008).

Among the 47 species of marine mammals that visit and live in the Patagonian shelf region, around half of them have been seen in the SJG (Retana 2013). Two of them reproduce in the SGJ coast (Otariaflavescens and Arctocephalus australis), two are considered vulnerable worldwide (Balaenoptera musculus and Megaptera novaeangliae, IUCN 2016) and two are endemic species or with a very restricted global distribution: Atlantic coasts of South America (Lagenorhynchus australis and Cephalorhynchus commersonii, Foro para la Conservación del Mar Patagónico y Áreas de Influencia 2008).
Consequently, the SJG is an excellent scenario to evaluate richness habitat models of marine species and their relationship not only with fixed physiographic variables but also with primary productivity and proximity to tidal fronts. The objective of this paper was to analyze the environmental variables that may explain the habitat suitability of 9 species of marine mammals and to explore the overlap of the predicted richness of marine mammals with the frontal areas of the San Jorge Gulf during the austral summer.

Globally, the distribution patterns of marine mammals appear to be correlated with productive zones associated with major water mass transitions, currents, nutrient flow connected to upwellings and bathymetric features (Tynan et al. 2005, Chavez \& Messie 2009, Bost et al. 2009). However, these relationships have been less studied in the South Atlantic Ocean and at smaller scales, so the effect of fronts on species diversity is less clear and remains poorly understood (Bost et al. 2009, Tittensor $e t$ al. 2010, Kaschner et al. 2011). The fact that studies of the relationship between the diversity of marine mammals and the environment are scarce is caused by the poor detectability of these animals (elusive and high mobile) that often translates into small sample sizes, restricted areas, seasonal movements, and/ or short study durations (Redfern et al. 2006). This work integrates data from different sources, like open biodiversity databases, systematic or observational surveys and uses species distribution models (SDM) based on statistical and mapping procedures by robust methods (Franklin 2009).

\section{MATERIALS AND METHODS}

\section{STUdy AREA}

The San Jorge Gulf (4559'S, $6641^{\prime} \mathrm{W}$ ) is a semi-open basin in central Patagonia and the largest gulf in Argentina (39,340 $\mathrm{km}^{2}$ ) with maximum depths close to $100 \mathrm{~m}$ in the central west area (Fig. 1a). The SJG is well connected with the Argentine plateau and strongly influenced by the energy of tides and the dominant Western and Southern winds (Tonini et al. 2006). The isobaths of $90 \mathrm{~m}$ provided an elliptical shape with the major axis in a northeast-southwest direction. In the southeast sector there is a shallow threshold (30-60 m) that extends towards the north of the gulf. Except for the south, the slopes are steep, rapidly reaching depths of $60 \mathrm{~m}$. Within the gulf, sea temperatures fluctuate between 7 and $13^{\circ} \mathrm{C}$ and salinity between 33.2 and 33.6 (Roux et al. 1995, Fernández et al. 2007, 2008). The northern sector of the SJG is one of the most important coastal areas in terms of marine biodiversity in Patagonia (Fundación Patagonia Natural 1996), and includes a $750 \mathrm{~km}^{2}$ protected area: the Patagonia Austral Marine Park (Fig. 1a). 

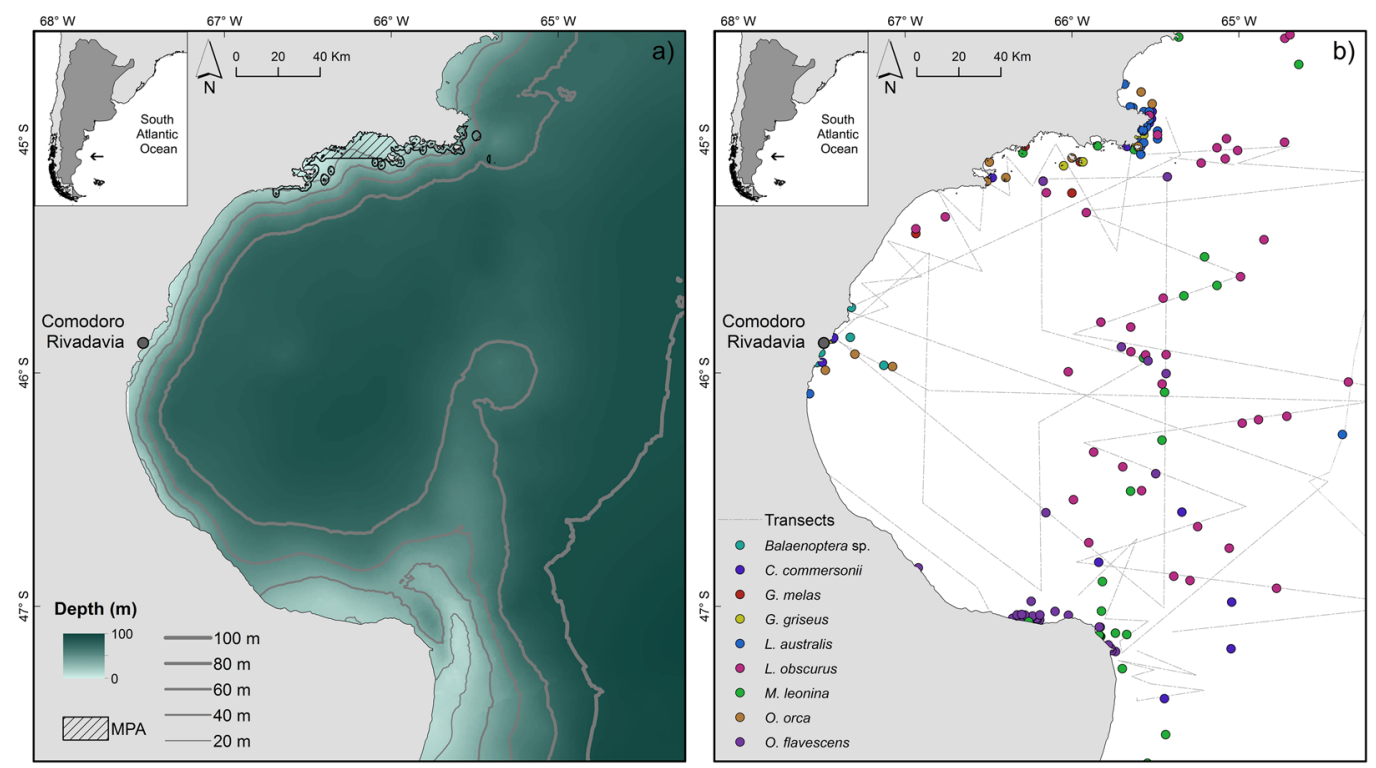

Figure 1. a) San Jorge Gulf, lines of iso baths each $20 \mathrm{~m}$, Patagonia Austral M arine Park in hatched area, and b) Records of occurrence of marine mammals and transects carried out during the oceanographic cruises BOPD 2009, Coriolis II 2014 and aerial surveys from Schiavini et al. (1999) / a) Golfo San Jorge, isobatas cada $20 \mathrm{~m}$ y el Parque Marino Patagonia Austral delimitado con rayas, y b) Ocurrencia de los registros de los mamíferos marinos y transectas realizadas en los cruceros BOPD 2009, Coriolis II 2014 y censos aéreos extraídos de Schiavini et al. (1999)

\section{BIOLOGICAL AND ENVIRONMENTAL DATA ANALYSIS}

From the 21 marine mammals species registered in the SJG (Retana 2013), we selected 9 species with more than 5 records for the analysis. The occurrence records of marine mammals were obtained from both systematic and occasional surveys (without measures of observational effort), and encompassed 205 georeferenced records. Database included sightings of individuals or pods during the months of November to March from surveys carried out by qualified observers along a line transect in 2 oceanographic cruises (BOPD 2009 and Coriolis II 2014, Fig. 1b) and aerial surveys (Schiavini et al. 1999). We also used records extracted from the Ocean Biogeographic Information System (OBIS, <www.iobis.org>, consulted on 13/ 01/2014) and the literature (Table 1). All the scientific names of marine mammals from the database were validated by matching them against WoRMS database ${ }^{1}$. The latitude and longitude of sightings were plotted on ArcGIS to detect the outliers. Several studies used marine biodiversity information from OBIS to understand the distribution and habitat suitability of different marine species (Best et al. 2007, Mora et al. 2008, Kot et al. 2010, Magris \& Déstro 2010, Tittensor et al. 2010, Gomez \& Cassini 2015). The spatial resolution was implemented based on Correlograms and Moran's I (Moran's autocorrelation coefficient, Haining 1990, Diniz-Filho et al. 2003), sampling grids were generated with a cell size of $5 \mathrm{~km}$, equal to the minimum distance between cells at which no spatial autocorrelation in biological data was recorded $(-0.2<$ Moran's $\mathrm{I}<0.2)$.

The potential distribution of the 9 marine mammal species was modeled using Maxent software version 3.3.3 (Phillips et al. 2004, Philips et al. 2006) and considering 6 environmental variables: bathymetry $(\mathrm{m})$, seafloor slope $\left(^{\circ}\right)$, distance to the coast $(\mathrm{m})$, distance to the fronts $(\mathrm{m})$, sea surface temperature $\left({ }^{\circ} \mathrm{C}\right)$ and chlorophyll $a\left(\mathrm{mg} \mathrm{m}^{-3}\right)$. In order to avoid collinearity, we selected the environmental variables whose correlation coefficient was less than 0.5. The sea surface temperature (SST) and chlorophyll $a$ concentration maps were obtained from level 3 SST and Chl $a$ images of the Aqua MODIS sensor (4.6 km resolution, <https://oceancolor.gsfc.nasa.gov/>), including data collected in the periods from November to March, 2002-2014. A monthly climatological map is a composite of all the data collected during a single calendar month along all the years selected. The maps were projected to Posgar 1994, clipped to the study area and re-sampled to a grid of $5 \mathrm{~km}$ cell size.

${ }^{1}<$ http://www.marinespecies.org/> 
Table 1. Taxonomy, conservation status and number of records for each species of marine mammals included in this study/ Taxonomía, estado de conservación y número de registros de cada especie de mamíferos marinos incluidas en este estudio

\begin{tabular}{|c|c|c|c|c|c|}
\hline Family & Species & Common Name & Status & Records & Source \\
\hline Balaenopteridae & $\begin{array}{l}\text { Balaenoptera } \mathrm{sp} . \\
(\text { B. borealis and B. bonaerensis) }\end{array}$ & & $\mathrm{EN} / \mathrm{DD}$ & 6 & $\begin{array}{l}\text { BOPD } 2009 \\
\text { Belgrano et al. } 2007 \\
\text { Reyes } 2006 \\
\text { Coriolis II }\end{array}$ \\
\hline \multirow[t]{6}{*}{ Delphinidae } & Cephalorhynchus commersonii * & Commerson's dolphin & DD & 22 & $\begin{array}{l}\text { Reyes } 2006 \\
\text { Coriolis II } 2014\end{array}$ \\
\hline & Globicephala melas & Long-finned pilot whale & DD & 5 & Reyes 2006 \\
\hline & Grampus griseus & Risso's dolphin & $\mathrm{LC}$ & 11 & $\begin{array}{l}\text { Reyes } 2006 \\
\text { Riccialdelli et al. } 2011\end{array}$ \\
\hline & Lagenorhynchus australis* & Peale's dolphin & DD & 29 & $\begin{array}{l}\text { BOPD } 2009 \\
\text { Reyes } 2006\end{array}$ \\
\hline & Lagenorhynchus obscurus & Dusky dolphin & DD & 40 & $\begin{array}{l}\text { Crespo et al. } 1997 \\
\text { Reyes } 2006 \\
\text { Schiavini et al. } 1999 \\
\text { Coriolis II } 2014\end{array}$ \\
\hline & Orcinus orca & Killer whale & DD & 14 & Reyes 2006 \\
\hline Otariidae & Otaria flavescens & South American sea lion & $\mathrm{LC}$ & 50 & $\begin{array}{l}\text { Campagna et al. } 2006 \text { a } \\
\text { Coriolis II } 2014\end{array}$ \\
\hline Phocidae & Mirounga leonina & Southern elephant seal & $\mathrm{LC}$ & 28 & $\begin{array}{l}\text { Lewis et al. } 2006 \\
\text { Campagna et al. } 2006 \text { a } \\
\text { Coriolis II } 2014\end{array}$ \\
\hline
\end{tabular}

(*) Endemic species

(DD) Data deficient, (EN) Endangered, (LC) Least concern, extracted from IUCN (2016)

BOPD (Oceanographic Cruise Puerto Deseado): summer 2009, CORIOLIS II: summer 2014

Bathymetry of the study area was digitized from nautical charts (H3 1:1500000 and H310 1:350000) and interpolated using Kriging geostatistical method to create a raster surface from points of depth. Seafloor slope, in degrees, was derived from the same bathymetry model using the spatial analysis tools of ArcGIS 9.3 and a grid cell size of $5 \mathrm{~km}$. Distance to the coast and to the fronts were calculated as the measure of a point (centre of each grid cell) to the nearest line (shoreline and front, respectively) using ArcGIS 9.3.

Fronts, defined as a rapid change in SST over a short distance as a result of the interface between two water masses, were identified in the SST raster images using the Cayula \& Cornillon (1992) single image edge detection (SIED) algorithm with the Marine Geospatial Ecology Tools (MGET, <http:// mgel.env.duke.edu/mget $>$ ). The algorithm localizes fronts where there is a significant difference between the mean temperatures of the two water masses. The parameters of the algorithm included a histogram window size of 16 x 16 and a histogram window stride of 4 pixels. We overlapped all monthly fronts obtained by SIED algorithm to delimit a frontal area (Fig. 2, hatched area). We used a Mann-Whitney U test ( $\alpha=0.05)$, to test the distance between the marine mammals records and frontal areas.

\section{SPECIES DISTRIBUTION MODELS: MAXeNT}

For spatial identification, SDM have two main uses: 1) one is based in generating species richness maps from the sum of individual models of each species; and 2) is based on modeling and subsequent analysis of the potential distribution of each species in order to determine relevant areas where the conservation efforts should be concentrated. SDMs have been applied to the assessment and prediction of changes in the habitats of many marine species (MacLeod et al. 2008, Whitehead et al. 2008, Praca et al. 2009, Moura et al. 2012). SMDs of marine mammals are often used to understand the interaction with fisheries (Torres et al. 2003, Kaschner et al. 2006), habitat conservation (Bailey \& Thompson 2009, Embling et al. 2010) or climate change (Freitas et al. 2008).

Maxent is a machine-learning technique based on the principle of maximum entropy from presence-only data, especially efficient to handle complex interactions between response and predictor variables and little sensitive to small sample sizes. Maxent can be used even with a scarce number of records per species, showing and excellent predictive capability when the sample size is small (Hernandez et al. 2006, Wisz et al. 2008). Pearson et al. (2007) demonstrated a significant predictive ability for Maxent models with as few as 5 observed localities. The model was selected for its apparent 

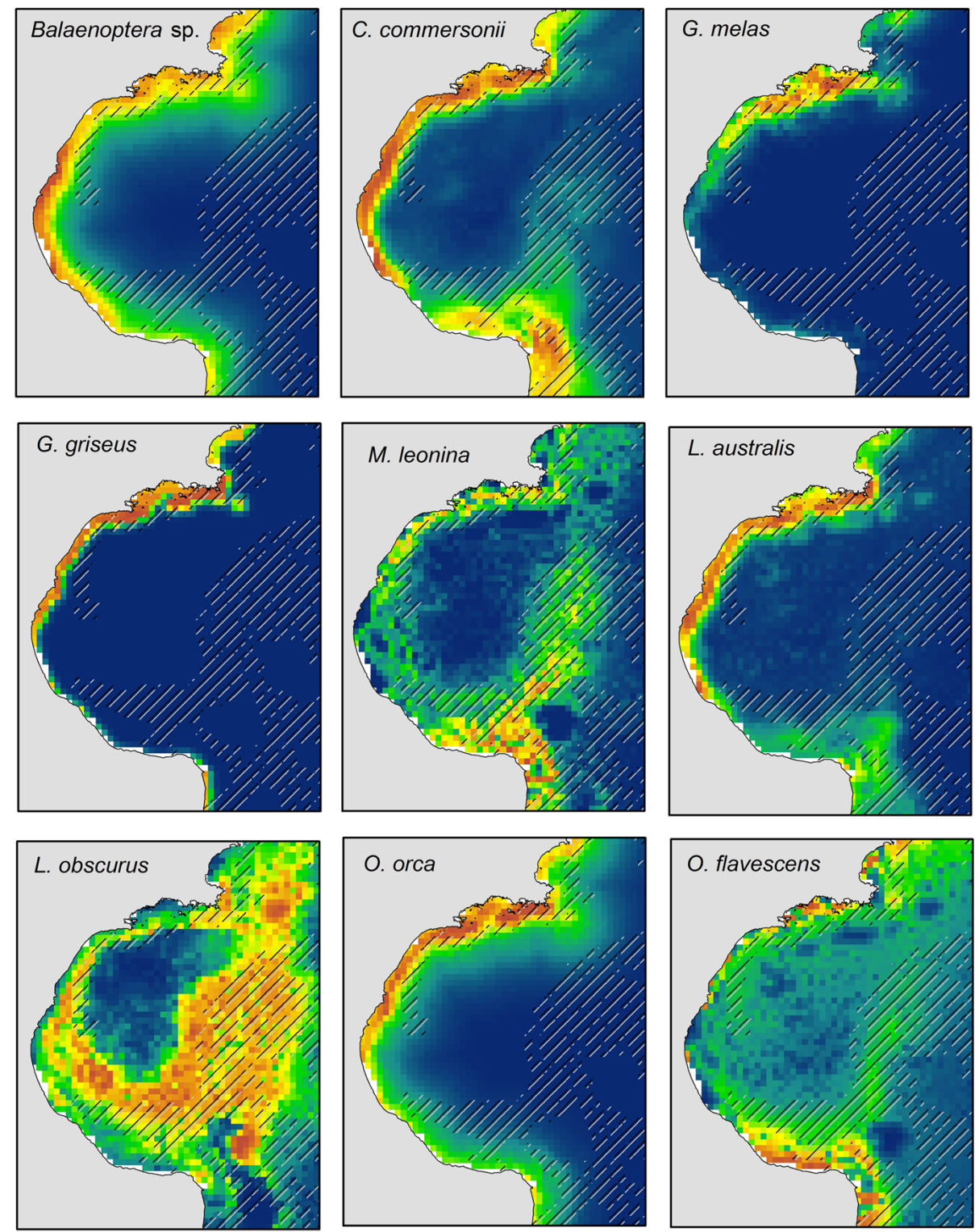

"If / /, Thermal Front Area

Habitat Suitability
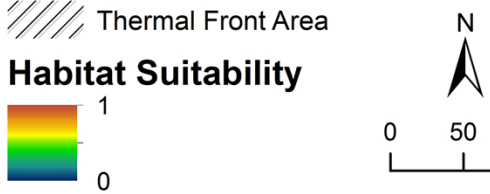

$0 \quad 50 \quad 100 \mathrm{Km}$

0

Figure 2. Predictive distribution of marine mammal species obtained from M axent model for each species and the thermal front area (hatched area) / Distribución predictiva de las 9 especies de mamíferos marinos obtenida a partir del modelo Maxent para cada especie y áreas frontales térmicas (área sombreada) 
comparatively high performance in relation to other modeling methods (Elith et al. 2006 for a review), it has also been used successfully to predict the distributions of marine mammals (Friedlaender et al. 2011, Moura et al. 2012, Bombosch et al. 2014, Gomez \& Cassini 2015, Svendsen et al. 2015).

The Maxent model were fitted using default parameters: a convergence threshold of $10^{-5}$, a maximum iteration value of 500 and automatic regularization with a value $10^{-4}$; following Phillips \& Dudik (2008). A cross-validation procedure was used to evaluate the performance of the model. Five random partitions of the occurrence points per species were made, each partition shaped by randomly selecting $80 \%$ of the occurrence points as training data and $20 \%$ of the occurrence points as testing data (Phillips et al. 2006). We created 9 bias grids from a Gaussian kernel density map of the occurrence locations of each species and rescaled from 1 to 20 following Elith et al. (2010). These grid files were used in the bias file option in the Maxent model. A jackknife test was used to examine the importance of each environmental variable by excluding one at a time and creating a model with the remaining variables. A threshold-independent measure, the AUC (area under the curve), was used to assess the predictive performance of the model. Models with an AUC $>0.7$ have good discriminatory power (Hosmer \& Lemeshow 1989). The species distributional models were projected as maps of potential areas, choosing a maximum training sensitivity plus specificity threshold of estimated occurrence (suitable habitat) because it is a robust method for data that contains both biases and errors (Varela et al. 2014). The maps obtained for each species of potential distributional areas were summed in ArcGIS 9.3 to obtain a unique map showing the number of predicted species in each pixel, namely map of predicted richness (Graham \& Hijmans 2006, Pineda \& Lobo 2012).

\section{Results}

Dynamics and seasonal variables, as Chl- $a$ and SST, observed between November and March of 2002-2014 delimited different environments in the gulf: two areas with thermal fronts, one in the northern sector following the northwest coast and another in the southeast sector of the gulf (hatched area in Fig. 2). The mean Chl- $a$ concentration varied between 1.15 and $3.90 \mathrm{mg} \mathrm{m}^{-3}$ in the north and center of the gulf; and between 2.91 and $6.28 \mathrm{mg} \mathrm{m}^{-3}$ in the southwest coast and following the southern threshold. Mean SST was around $15^{\circ} \mathrm{C}$ in the middle of the gulf, decreasing towards the southeast where temperatures reached the lowest $\left(11.34^{\circ} \mathrm{C}\right)$ and towards the north where temperatures reached the $15.5^{\circ} \mathrm{C}$. In the area of the southeast front, the correlation between SST and Chl- $a$ was positive ( $\mathrm{r}=$ 0.15 ) and the chlorophyll concentration was higher, reaching $3.1 \mathrm{mg} \mathrm{m}^{-3}$. Nineteen percent of the marine mammal records
Table 2. Predictive performance of the Maxent models showing the threshold-independent measure AUC (mean and SD) for each species / Resultado de los modelos predictivos de Maxent, valores de AUC (media y desviación estándar) para cada especie

\begin{tabular}{lc}
\hline \multicolumn{1}{c}{ Species } & $\begin{array}{c}\text { AUC } \\
\text { (mean } \pm \text { SD) }\end{array}$ \\
\hline Balaenoptera sp. & $0.96 \pm 0.09$ \\
Cephalorhynchus commersonii & $0.89 \pm 0.04$ \\
Globicephala melas & $0.96 \pm 0.06$ \\
Grampus griseus & $0.97 \pm 0.01$ \\
Lagenorhynchus australis & $0.81 \pm 0.09$ \\
Lagenorhynchus obscurus & $0.80 \pm 0.05$ \\
Mirounga leonina & $0.81 \pm 0.07$ \\
Orcinus orca & $0.94 \pm 0.07$ \\
Otaria flavescens & $0.85 \pm 0.07$ \\
\hline
\end{tabular}

were found in frontal areas, while the remaining locations were closer to the frontal areas (mean \pm SE: $9.48 \pm 7.30 \mathrm{~km}$ ) than expected by chance $(13.34 \pm 12.01 \mathrm{~km}$, Mann-Whitney U test, $\left.\mathrm{Z}_{\text {adj }}=-1.99, P<0.05\right)$.

The predicted distribution of 9 marine mammal species was not random, with AUC values greater than 0.80 and low standard deviations, indicating uniformity among partitions (Table 2). Fixed variables as bathymetry, slope and distance to the coast were the most important environmental factors defining habitat suitability of all species; however, variable contributions were different between species. Most species occurred along the SJG coast following the shape of the $80 \mathrm{~m}$ isobaths (Fig. 1b), and highly suitable habitats covered $43 \%$ of the gulf. Balaenoptera sp., G. melas, G. griseus, L. australis and $O$. orca showed a coastal distribution localized mainly in the northwest coast (Fig. 2), being the distance to the coast the most important variable affecting their distributions (Fig. 3). The suitable habitat for Balaenoptera sp. was located in waters with a concentration of Chl- $a$ up to $2.5 \mathrm{mg} \mathrm{m}^{-3}$ and close to the northwest coast (less than $20 \mathrm{~km}$ from shoreline). For G. melas, the best habitat was a restricted area until $40 \mathrm{~km}$ from the north coast of the gulf with SST higher than $14.5^{\circ} \mathrm{C}$. The suitable habitat for G. griseus was similar to G. melas reaching the area close to Comodoro Rivadavia city but restricted to $10 \mathrm{~km}$ from the coast. L. australis and $O$. orca showed similar habitats along the northwest coast between 13 and $20 \mathrm{~km}$ from the shoreline, respectively, and with slope higher than $0.15^{\circ}$. The distributions of both pinnipeds (M. leonina and O.flavescens) and the small cetacean $C$. commersonii followed the shape of the coast up to the $80 \mathrm{~m}$ isobaths, with the bathymetry as the most important variable determining the habitat suitability of these 


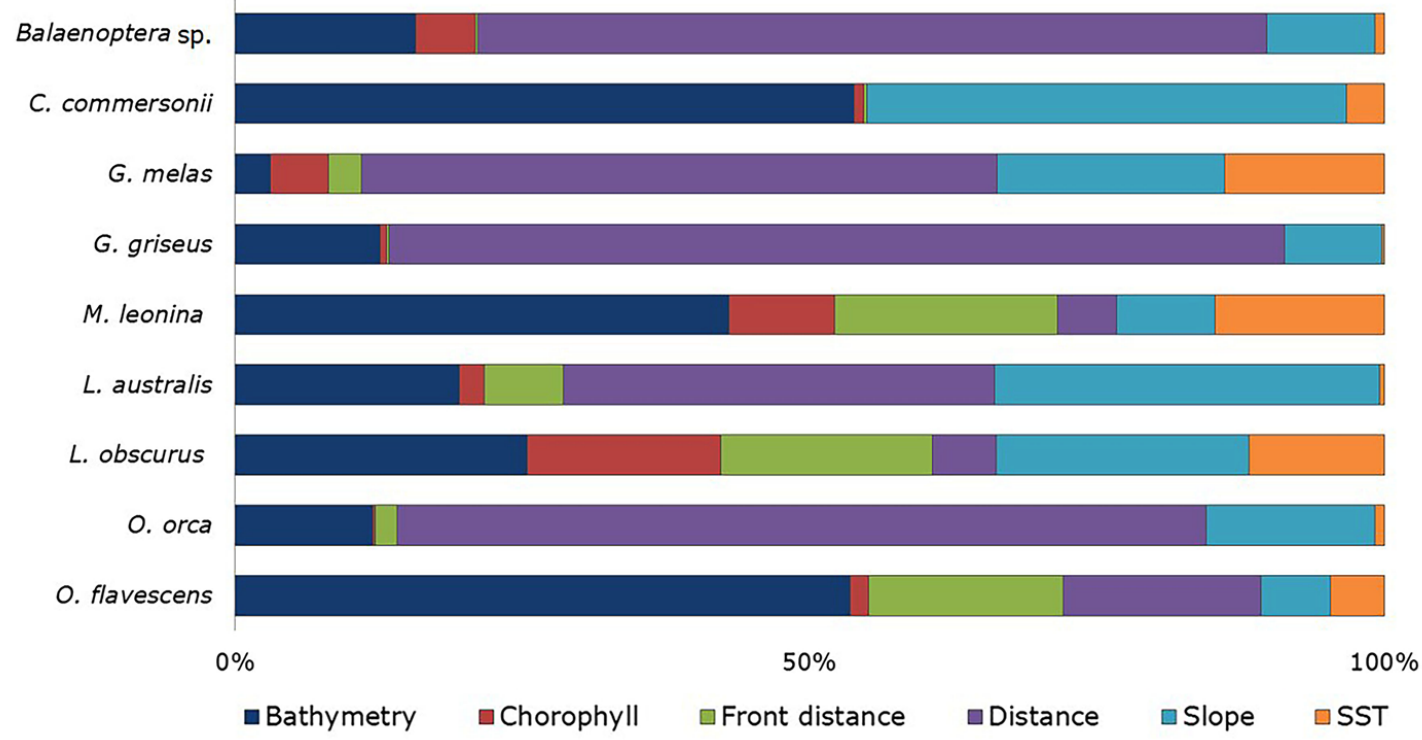

Figure 3. Percentage contribution of the fixed and dynamics environmental variables to the Maxent distribution models for each marine mammal species in SJG / Porcentajes de contribución de las variables ambientales (fijas y dinámicas) obtenidos de los modelos de distribución de Maxent para cada especie de mamífero marino en el Golfo San Jorge

species (> 43\%, Fig. 2). The best habitat for M. leonina and O. flavescens was located in waters with depth less than $75 \mathrm{~m}$ and a distance below $1 \mathrm{~km}$ from the frontal area. The suitable habitat for $C$. commersonii was shallower than that of the pinnipeds (less than $50 \mathrm{~m}$ ) and with slopes of at least $0.20^{\circ}$. For L. obscurus, the potential distribution was homogeneous throughout the SJG at suitable habitat with slopes greater than $0.25^{\circ}$ and depths between 40 and $60 \mathrm{~m}$ (Fig. 2). Although the front distance was not reflected as an important variable in the models, except for $O$. flavescens $(17.2 \%)$ and M. leonina (19.4\%), around $50 \%$ of the potential distribution of marine mammals overlapped with the frontal areas (Fig. 2).

The area with higher predicted richness ( 8 species, all except L. obscurus) was located along the northwest coast of the SJG, and showed a $75 \%$ overlap with the frontal area. Following the threshold of the southeast front there was another area with 4 species (O. flavescens, M. leonina, C. commersonii and $L$. obscurus, Fig. 4). Both predicted richness areas were found where the mean depth was $48.13 \pm 21.46 \mathrm{~m}$, the mean slope was $0.12 \pm 0.06^{\circ}$, and the Chl- $a$ concentration varied between 2.18 and the maximum of $6.28 \mathrm{mg} \mathrm{m}^{-3}$.

\section{Discussion}

This study, showed that the habitat suitability of 9 marine mammals in the SJG was better defined by fixed variables like bathymetry, slope and distance to the coast than by the dynamic ones, and the highest predicted richness of marine mammals was spatially consistent with frontal zones. These areas were selected by resident species that inhabit the coastal area like $C$. commersonii, L. australis, L. obscurus, O. flavescens, and $O$. orca; oceanic species as G. griseus, M. leonina, and $G$. melas; and species of large seasonal migrations as balaenopterids.

Bathymetry defines areas that often result in greater nutrient mixing induced by topography (Sverdrup et al. 1942, Guerra 1992, Rubín 1997), favoring the retention of eggs and larvae (Ehrlich \& Ciechomski 1994, Ehrlich et al. 2001, Bakun 2006) and the aggregation of prey organisms. Depth, slope and physiography directly affect the distribution of benthic or demersal prey (Gil de Sola 1993) and, indirectly, other trophic levels. The physiography acts indirectly through mechanisms such as the upwelling induced by topography (Guerra 1992, Rubín 1997), due to an increase in the primary production and aggregation of zooplankton by the secondary production (Rubín et al. 1992). Therefore, it is to be expected that the distribution of marine mammals in the SJG has been to be associated with those environmental variables that generate frontal areas and act directly on the distribution of main preys. Besides of foraging, other behaviors such as sheltering, resting, travelling, or socializing would seem to be the main factors that guide the selection of the habitat in small cetacean. Proximity to the coast 


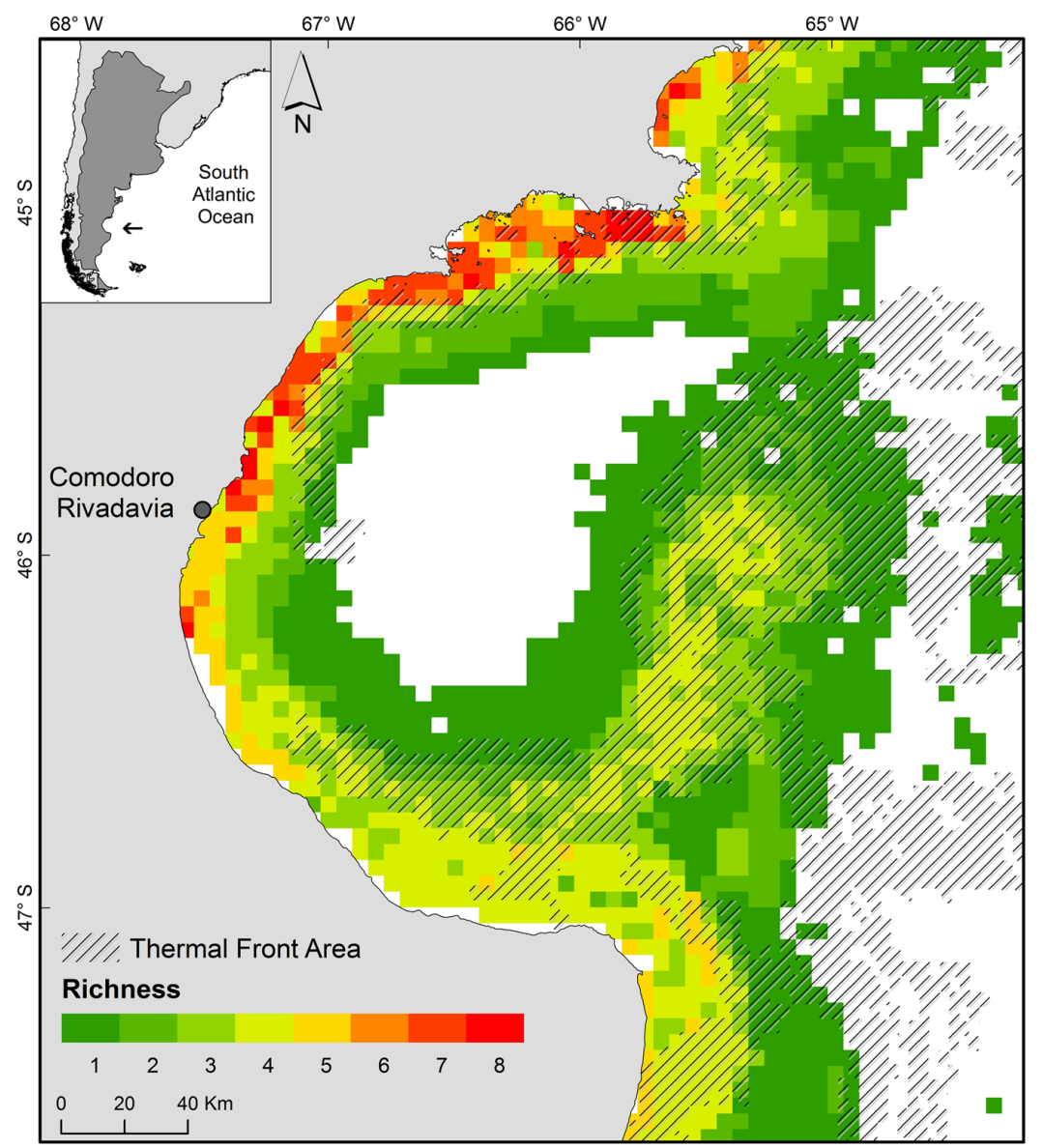

Figure 4. Predicted richness areas of 9 marine mammal species constructed by overlapping the potential area of each species with a conditional probability of occurrence $\geq \mathbf{0 . 5}$ / Áreas de riqueza predicha de 9 especies de mamíferos marinos construida a partir de la superposición de las áreas potenciales de cada especie con una probabilidad de ocurrencia $\geq 0,5$

would increase protection against potential predators, particularly for small groups or those consisting of mothers with calves (Würsig \& Würsig 1979, 1980; Garaffo et al. 2007). Several species of marine mammals show a variety of responses to the presence of $O$. orca, including active defense, fleeing, hiding or changing group size, sometimes indicating a change in their distribution (Jefferson et al. 1991). The predation by sharks in different species of dolphins and pinnipeds (Crespi-Abril et al. 2003) could act as a very important factor for the selection of resting (Wells \& Norris 1994, Heithaus \& Dill 2002) and breeding habitats (Wells et al. 1980, Mann et al. 2000).

Despite the low number of records used in this study, environmental variables that influence the distribution of marine mammals agreed with those found in other systematic studies focused on isolated/single species as the dusky dolphin (Garaffo 2009, Garaffo et al. 2010, 2011; Svendsen et al. 2015),
Peale's dolphin (Viddi \& Lescrauwaet 2005, Viddi et al. 2010), Commerson's dolphin (Coscarella et al. 2011, Garaffo et al. 2011, Loizaga de Castro et al. 2013) sea lions (Svendsen 2013, Baylis et al. 2016) or southern elephant seals (Campagna et al. 2007). For L. obscurus the most important environmental variables that affected their potential distribution were bathymetry and slope, showing a suitable habitat in shallower areas with steep slopes. Both variables and distance to the coast, explained the distribution in other Patagonian gulfs where there was no influence of tidal fronts (Garaffo et al. 2010, 2011; Svendsen et al. 2015). In this case, the distance to the coast was not a significant variable due to the threshold located in the south of the SJG where at large distance from the coast the depth still remains shallow. The model of $C$. commersonii showed a coastal distribution similar to that found by Garaffo et al. (2011) along the Patagonian coast; however, the distance 
to the nearest river mouth was a significant variable that explained their distribution. C. commersonii usually is associated with estuaries, wide continental shelves, wide tidal cycles and cool waters (Brownell \& Donovan 1988, Goodall et al. 1988, Goodall 1994, Pedraza 2008, Coscarela et al. 2010, Loizaga de Castro et al. 2013). The difference between the variables of this study and those found in previous ones could be because there are no mouths of rivers or estuarine zones inside the SJG.

For pinnipeds (O. flavescens and M. leonina), the bathymetry was the most important environmental variable that explained their distribution. Studies of habitat selection of $O$. flavescens and M. leonina using satellite tracking showed that the presence of these species is a consequence of the distribution of their prey in shallow waters (Campagna et al. 2001, 2006b). The reproductive season of $O$. flavescens is in the warm season, so the energetic requirements of their pups would require short foraging trips near to the rockeries, mainly in the first period of lactation (Campagna et al. 2001). M. leonina is a deep diver feeder, however some young seals remain in shallow waters with physical features of the mid-shelf region, such as thermal fronts (Campagna et al. 2007). This behavior of feeding in shallow and productive waters are in agreement with our results, where the bathymetry and the distance to the fronts were the most significant variables.

The modelled distribution for L. australis was restricted to the northwest coast until $13 \mathrm{~km}$ of the shoreline where finescale processes occur, like eddies and fronts induced by topography. Their distribution could be associated with kelp forests of Macrocystis pyrifera, as mentioned by other authors (de Haro \& Iñiguez 1997, Goodall et al. 1997, Lescrauwaet 1997 , Viddi \& Lescrauwaet 2005). The main prey of $L$. australis are fishes associated with the kelp forest such as Genypterus blacodes and Merluccius hubbsi, among others (Schiavini et al. 1997). No other works in the literature were found that tried to address habitat preferences of $O$. orca in Argentina; however, in the U.S. Atlantic and the Gulf of Mexico the distribution was relatively uniform on and off the shelf (Roberts et al. 2016). The distance to the coast was the most important variable to explain their northwest distribution in the SJG, due probably to the proximity to rockeries of $O$. flavescens and A. australis and their behavior of intentional stranding while hunting nearshore (López \& López 1985, Hoelzel 1991, Vila et al. 2008, Grandi et al. 2012). In northern Patagonia, the seasonal distribution of $O$. orca is correlated with the distribution of the rockeries of $O$. flavescens and $M$. leonina, being the encounters more frequent during the sea lion breeding cycle in December and March (Iñiguez 2001). The overlapped distribution of $O$. orca and L. australis along the northwest coast could be another case of potential predatory threat, Viddi \& Lescrauwaet (2005) observed individuals of $O$. orca with some frequency in the area of occurrence of $L$. australis, but there were not observations of predation.

In the present study, the distribution of non-resident and occasional species of the SJG was modeled. The presence and potential distribution of G. griseus and G. melas in shallow coastal waters of the SJG do not fit the habitat requirements predicted in other regions, where both species occur in oceanic waters along the continental slope (Abend \& Smith 1999, Jefferson et al. 2014, Roberts et al. 2016). For example, G. griseus preferred shelf-edge habitats with depths between 400 and $1000 \mathrm{~m}$ and has been seen in coastal areas only if the continental shelf is near the coast (Leatherwood et al. 1980, Baumgartner 1997, Baird 2002). In the SJG, Belgrano et al. (2007) described that the balaenopterids were travelling, suggesting that the gulf is an important area for the migration of this species. These whales undertake large seasonal migrations moving into cold, productive waters in summer to feed and travelling to warmer, calmer waters in winter to calve or breed (Roberts et al. 2016).

It is known that the distribution patterns of marine mammals seem to be correlated with productive zones. This work highlights the importance of the SJG frontal areas in relation to other areas of the Patagonian coast since this area congregated both oceanic and coastal species of marine mammals. Half of the resident marine mammals as well as seasonal and occasional visitors from the Patagonian shelf region were recorded in the SJG, and in around $40 \%$ it was possible to model their distribution inside the gulf, showing that it was not random. The use of SDM was beneficial to improve the knowledge about environmental variables that can be playing a key role on the top predator's distribution. Around 50\% of the potential distribution overlapped with the frontal areas including 2 endemic species with a restricted distribution in the southern Hemisphere, C. commersonii and L. australis. Higher predicted richness was located along the northwest coast of the SJG. The Northwest showed a $75 \%$ overlap with the frontal area and only $2 \%$ of suitable area overlapped with the protected area included in the Patagonia Austral Marine Park. Further studies related to ocean circulation, ecosystem structure and function will be needed to determine the impact that the changes in the dynamic variables could have on species distribution. At the moment, our results increase the understanding of seasonally suitable habitats of marine mammals in the SJG; furthermore, the potential distribution maps of these species establish a baseline to design future surveys at other spatial or temporal scales and different environmental variables. 


\section{ACKNOWLEDGEMENTS}

We are thankful for the academic support given to this $\mathrm{PhD}$ research by National Research Council of Argentina, CONICET. We thank Dr. N. Dellabianca for providing the observational data of BOPD, as well as the assistants, technicians, and the crew of the RV 'Coriolis II' who participated in this work, and the anonymous reviewers for their helpful suggestions on an early version of the manuscript.

\section{LITERATURE CITED}

Abend A \& TD Smith. 1999. Review of the distribution of the long-finned pilot whale (Globicephala melas) in the North Atlantic and Mediterranean. NOAATechnical Memorandum NMFS-NE-117: 1-22. <https://www.nefsc.noaa.gov/nefsc/ publications/tm/tm117/>

Acha EM, HW Mianzan, RA Guerrero, M Favero \& J Bava. 2004. Marine fronts at the continental shelves of austral South America. Physical and ecological processes. Journal of Marine Systems 44(1-2): 83-105.

Akselman R. 1996. Estudios ecológicos en el Golfo San Jorge y adyacencias (Atlántico sudoccidental). Distribución, abundancia y variación estacional del fitoplancton en relación a factores físico-químicos y a la dinámica hidrográfica. $\mathrm{PhD}$ Thesis, Facultad de Ciencias Exactas y Naturales, Universidad de Buenos Aires, Buenos Aires, 269 pp.

Bailey H \& PM Thompson. 2009. Using marine mammal habitat modelling to identify priority conservation zones within a marine protected area. Marine Ecology Progress Series 378: 279-287.

Baird RB. 2002. Risso's dolphin Grampus griseus. In: Perrin WF, BJ Würsig \& JGM Thewissen (eds). Encyclopedia of marine mammals, pp. 1037-1039. Academic Press, San Diego.

Bakun A. 2006. Fronts and eddies as key structures in the habitats of marine fish larvae: opportunity, adaptive response and competitive advantage. Scientia Marina 70: 105-122.

Ballance LT, RL Pitman \& PC Fiedler. 2006. Oceanographic influences on seabirds and cetaceans of the eastern tropical Pacific. A review. Progress in Oceanography 69: 360-390.

Baumgartner MF. 1997. The distribution of Risso's dolphin (Grampus griseus) with respect to the physiography of the northern Gulf of Mexico. Marine Mammal Science 13(4): 614-638.

Baylis AMM, RA Orben, DP Costa, JPY Arnould \& IJ Staniland. 2016. Sexual segregation in habitat use is smaller than expected in a highly dimorphic marine predator, the southern sea lion. Marine Ecology Progress Series 554: 201211.

Belgrano J, J Masello, C Gribaudo, D Arcucci, F Krohling, M Failla \& M Iñíguez 2007. Sightings of sei whales (Balaenoptera borealis) on the South Western Atlantic.
Anchorage, Alaska. SC/59/SH13: 1-3.

Benoit-Bird KJ, BC Battaile, SA Heppell, B Hoover, D Irons, N Jones, KJ Kuletz, CA Nordstrom, R Paredes, RM Suryan, CM Waluk \& AW Trites. 2013. Prey patch patterns predict habitat use by top marine predators with diverse foraging strategies. PloS One 8(1): e53348. < https:/ /doi.org/10.1371/journal.pone.0053348>

Best BD, PN Halpin, E Fujioka, AJ Read, SS Qian, LJ Hazen \& RS Schick. 2007. Geospatial web services within a scientific workflow: Predicting marine mammal habitats in a dynamic environment. Ecological Informatics 2(3): 210223.

Bombosch A, DP Zitterbart, I Van Opzeeland, S Frickenhaus, E Burkhardt, MS Wisz \& O Boebel. 2014. Predictive habitat modelling of humpback (Megaptera novaeangliae) and Antarctic minke (Balaenoptera bonaerensis) whales in the Southern Ocean as a planning tool for seismic surveys. Deep Sea Research Part I: Oceanographic Research Papers 91: 101-114.

Bost CA, C Cotté, F Bailleul, Y Cherel, JB Charrassin, C Guinet, DG Ainley \& H Weimerskirch. 2009. The importance of oceanographic fronts to marine birds and mammals of the southern oceans. Journal of Marine Systems 78:363-376.

Brownell RL \& GP Donovan. 1988. The biology of the genus Cephalorhynchus. Reports of the International Whaling Commission 9: 1-344.

Campagna C, R Werner, W Karesh, MR Marin, F Koontz, R Cook \& C Koontz. 2001. Movements and location at sea of South American sea lions (Otaria flavescens). Journal of Zoology 257: 205-220.

Campagna C, MN Lewis \& MR Marin. 2006a. Locations of seals in Patagonian Large Marine Ecosystem. In: Ashore and at sea distribution of seals. Centro Nacional Patagónico, Puerto Madryn. <http://www.iobis.org>

Campagna C, AR Piola, MR Marin, MN Lewis \& T Fernández. 2006b. Southern elephant seal trajectories, ocean fronts and eddies in the Brazil/Malvinas Confluence. Deep-Sea Research, Part 1. Oceanographic Research Papers 53: 1907-1924.

Campagna C, AR Piola, MR Marin, M Lewis, U Zajaczkoski \& T Fernández. 2007. Deep divers in shallow seas: Southern elephant seals on the Patagonian shelf. DeepSea Research. Part I. Oceanographic Research Papers 54: 1792-1814.

Cayula JF \& P Cornillon. 1992. Edge detection algorithm for SST images. Journal of Atmospheric and Oceanic Technology 9:67-80.

Certain G, J Masse, OV Canneyt, P Petitgas, G Doremus, MB Santos \& V Ridoux. 2011. Investigating the coupling between small pelagic fish and marine top predators using data collected from ecosystem-based surveys. Marine Ecology Progress Series 422: 23-39. 
Chavez FP \& M Messie. 2009. A comparison of eastern boundary upwelling ecosystems. Progress in Oceanography 83: 80-96.

Coscarella MA, SN Pedraza \& EA Crespo. 2010. Behavior and seasonal variation in the relative abundance of Commerson's dolphin (Cephalorhynchus commersonii) in northern Patagonia, Argentina. Journal of Ethology 28(3): 463-470.

Crespi-Abril AC, NA García, EA Crespo \& MA Coscarella. 2003. Consumption of marine mammals by broadnose sevengill shark Notorynchus cepedianus in the northern and central Patagonian shelf. Latin American Journal of Aquatic Mammals 2(2): 101-107.

Crespo EA, SN Pedraza, MA Coscarella, NA García, SL Dans, M Iñiguez, LM Reyes, M Koen-Alonso, ACM Schiavini \& R González. 1997. Distribution and school size of dusky dolphins Lagenorhynchus obscurus (Gray, 1828) in the Southwestern South Atlantic Ocean. Reports of the International Whaling Commission 47: 693-698.

Dalla Rosa L, JKB Ford \& AW Trites. 2012. Distribution and relative abundance of humpback whales in relation to environmental variables in coastal British Columbia and adjacent waters. Continental Shelf Research 36: 89-104.

de Haro JC \& M Iñiguez. 1997. Ecology and behavior of the Peale's dolphin, Lagenorhynchus australis (Peale, 1848), at Cabo Virgenes (52 $30^{\prime} \mathrm{S}, 68^{\circ} 28^{\prime} \mathrm{W}$ ), in Patagonia, Argentina. Reports of the International Whaling Commission 47(Special Issue): 723-727.

Diniz-Filho JAF, LM Bini \& BA Hawkins. 2003. Spatial autocorrelation and red herrings in geographical ecology. Global Ecology \& Biogeography 12: 53-64.

Doniol-Valcroze T, D Berteaux, P Larouche \& R Sears. 2007. Influence of thermal fronts on habitat selection by four rorqual whale species in the Gulf of St. Lawrence. Marine Ecology Progress Series 335: 207-216.

Ehrlich MD \& JD Ciechomski. 1994. Reseña sobre la distribución de huevos y larvas de merluza (Merluccius hubbsi) basada en veinte años de investigación. Frente Marítimo 15(A): 37-50.

Ehrlich M, L Machinandiarena, D Brown, P Ibáñez \& E Leonarduzzi. 2001. Distribución y abundancia de prerreclutas de merluza (Merluccius hubbsi) en el litoral norpatagónico. Diciembre 2000-Junio 2001. Technical Report DNI-INIDEP 83: 1-24.

Elith J, CH Graham, RP Anderson, M Dudik, S Ferrier, A Guisan, RJ Hijmans, F Huettmann, JR Leathwick, A Lehmann, J Li, LG Lohmann, BA Loiselle, G Manion, C Moritz, M Nakamura, Y Nakazawa, J Overton, AT Peterson, SJ Phillips, KS Richardson, R ScachettiPereira, RE Schapire, J Soberón, S Williams, MS Wisz \& NE Zimmermann. 2006. Novel methods improve prediction of species' distributions from occurrence data. Ecography 29: 129-151.
Elith J, M Kearney \& SJ Phillips. 2010. The art of modelling range-shifting species. Methods Ecology Evolution 1: 330342

Embling CB, PA Gillibrand, J Gordon, J Shrimpton, PT Stevick \& PS Hammond. 2010. Using habitat models to identify suitable sites for marine protected areas for harbor porpoises (Phocoena phocoena). Biological Conservations 143: 267-279.

Fernández M, DA Cucchi Colleoni, A Roux, A Marcos \& E Fernández. 2007. Caracterización físico-química del sistema bentónico en el sector sur del Golfo San Jorge, Argentina. Revista de Biología Marina y Oceanografía 42(2): 177-192.

Fernández M, J Mora, A Roux, DA Cucchi-Colleoni \& JC Gasparoni. 2008. New contribution on spatial and seasonal variability of environmental conditions of the Golfo San Jorge benthic system, Argentina. Journal of the Marine and Biological Association of the United Kingdom 88(2): 227 236.

Foro para la Conservación del Mar Patagónico y Áreas de Influencia. 2008. Synthesis of the status of conservation of the Patagonian Sea and areas of influence, 336 pp, Fundación Patagonia Natural, Puerto Madryn.

Franklin J. 2009. Mapping species distributions: Spatial inference and prediction, 338 pp, Cambridge University Press, Cambridge.

Freitas C, KM Kovacs, RA Ims \& C Lydersen. 2008. Predicting habitat use by ringed seals (Phoca hispida) in a warming Arctic. Ecological Modelling 217: 19-32.

Friedlaender AS, DW Johnston, WR Fraser, J Burns, PN Halpina \& DP Costa. 2011. Ecological niche modeling of sympatric krill predators around Marguerite Bay, Western Antarctic Peninsula. Deep-Sea Research II 58: 1729-1740.

Fundación Patagonia Natural. 1996. Plan de Manejo Integrado de la Zona Costera Patagónica: diagnosis y recomendaciones para su elaboración, 110 pp. Fundación Patagonia Natural and Wildlife Conservation Society, Puerto Madryn.

Gannier A \& E Praca. 2007. SST fronts and the summer sperm whale distribution in the north-west Mediterranean Sea. Journal of the Marine Biological Association of the United Kingdom 87: 187-193.

Garaffo GV. 2009. Análisis espacio-temporal de la distribución y abundancia de delfines oscuros, Lagenorhynchus obscurus, en el norte y centro de Patagonia, 169 pp. Universidad Nacional del Comahue, Bariloche.

Garaffo GV, SL Dans, SN Pedraza, EA Crespo \& M Degrati. 2007. Habitat use by dusky dolphin in Patagonia: how predictable is their location? Marine Biology 152: 165-177.

Garaffo GV, SL Dans, EA Crespo, M Degrati, P Giudici \& DA Gagliardini. 2010. Dusky dolphin: modeling habitat selection. Journal of Mammalogy 91(1): 54-65. 
Garaffo GV, SL Dans, SN Pedraza, M Degrati, ACM Schiavini, R González \& EA Crespo. 2011. Modeling habitat use for dusky dolphin and commerson's dolphin in Patagonia. Marine Ecology Progress Series 421: 217-227.

Gil de Sola L. 1993. Las pesquerías demersales del Mar de Alborán (sur Mediterráneo ibérico). Evolución en los últimos decenios, 142 pp, Informes Técnicos, Instituto Español de Oceanografía 142: 1-179.

Goodall RNP. 1994. Commerson's dolphin, Cephalorhynchus commersonii (Lacépède, 1804). In: Ridgway S \& RJ Harrison (eds). Handbook of marine mammals. The first book of Dolphins, pp. 241-267. Academic Press, London.

Goodall RNP, AR Galeazii, S Leatherwood, KW Millar, IS Cameron, RK Kastelein \& AP Sobral. 1988. Studies of Commerson's dolphins, Cephalorhynchus commersonii, off Tierra del Fuego, 1976-1984, with a review of information on the species in the South Atlantic. In: Brownell RL Jr \& GP Donovan (eds). Biology of the genus Cephalorhynchus. Reports of the International Whaling Commission 9: 3-70.

Goodall RNP, JC de Haro, F Fraga, MA Iñiguez \& KS Norris. 1997. Sightings and behavior of Peale's dolphin, Lagenorhynchus australis, with notes on the dusky dolphin, L. obscurus, off southernmost South America. Reports of the International Whaling Commission 47(Special Issue): 757775 .

Gomez JJ \& MH Cassini. 2015. Environmental predictors of habitat suitability and biogeographical range of Franciscana dolphins (Pontoporia blainvillei), Global Ecology and Conservation 3: 90-99.

Graham CH \& RJ Hijmans. 2006. A comparison of methods for mapping species ranges and species richness. Global Ecology and Biogeography 15: 578-587.

Grandi MF, R Loizaga de Castro \& EA Crespo. 2012. Killer whales attack on South American sea lion associated with a fishing vessel: predator and prey tactics. Latin American Journal of Aquatic Research 40(4): 1072-1076.

Guerra A. 1992. Fauna Ibérica, Vol. 1. Mollusca: Cephalopoda, 328 pp. Museo Nacional de Ciencias Naturales, Consejo Superior de Investigaciones Científicas, Madrid.

Haining R. 1990. Spatial data analysis in the social and environmental sciences, 432 pp, Cambridge University Press, Cambridge.

Hazen EL, DP Nowacek, L St Laurent, PN Halpin \& DJ Moretti. 2011. The relationship among oceanography, prey fields, and beaked whale foraging habitat in the Tongue of the Ocean. PloS One 6: e19269. <doi:10.1371/journal. pone.0019269>

Heithaus MR \& LM Dill. 2002. Food availability and tiger shark predation risk influence bottlenose dolphin habitat use. Ecology 83: 480-491.

Hernandez PA, CH Graham, LL Master \& DL Albert. 2006. The effect of sample size and species characteristics on performance of different species distribution modeling methods. Ecography 29(5): 773-785.
Hoelzel AR. 1991. Killer whale predation on marine mammals at Punta Norte, Argentina: Food sharing provisioning and foraging strategy. Behavioral Ecology and Sociobiology 29: 197-204.

Hosmer DW \& S Lemeshow. 1989. Applied logistic regression, 307 pp. Wiley, New York.

Iñiguez MA. 2001. Seasonal distribution of killer whales (Orcinus orca) in Northern Patagonia, Argentina. Aquatic Mammals 27: 154-161.

IUCN. 2016. The IUCN Red List of Threatened Species. Version 2016.3. International Union for Conservation of Nature and Natural Resource. 〈http://www.iucnredlist.org>

Jefferson TA, PJ Stacey \& RW Baird. 1991. A review of killer whale interactions with other marine mammals: Predation to co-existence. Mammal Review 21: 151-180.

Jefferson TA, CR Weir, RC Anderson, LT Ballance, RD Kenney \& JJ Kiszka. 2014. Global distribution of Risso's dolphin Grampus griseus: a review and critical evaluation. Mammal Review 44(1): 56-68.

Kaschner K, R Watson, AW Trites \& D Pauly. 2006. Mapping worldwide distributions of marine mammals using a Relative Environmental Suitability (RES) model. Marine Ecology Progress Series 316: 285-310.

Kaschner K, DP Tittensor, J Ready, T Gerrodette \& B Worm. 2011. Current and future patterns of global marine mammal biodiversity. PloS One 6(5): e19653. <doi: 10.1371/ journal.pone.0019653>

Kot CY, E Fujioka, LJ Hazen, BD Best, AJ Read \& PN Halpin. 2010. Spatio-temporal gap analysis of OBISSEAMAP project data: Assessment and way forward. PLoS ONE 5(9): e12990. <doi: 10.1371/journal.pone.0012990>

Leatherwood S, WF Perrin, VL Kirby, CL Hubbs \& M Dahlheim. 1980. Distribution and movements of Risso's dolphin, Grampus griseus, in the eastern North Pacific. Fisheries Bulletin 77: 951-963.

Lescrauwaet A-K. 1997. Notes on the behavior and ecology of the Peale's dolphin, Lagenorhynchus australis, in the Strait of Magellan, Chile. Reports of the International Whaling Commission 47(Special Issue): 747-755.

Lewis MN, C Campagna \& MR Marin. 2006. Distribution ashore and breeding places of southern elephant seals in South America. In: Lewis MN (ed). Distribution of elephant seals. Centro Nacional Patagónico, Puerto Madryn. <http:// arobis.cenpat-conicet.gob.ar:8081/resource?r=arobis-sealsii $>$

Loizaga de Castro R, SL Dans, MA Coscarella \& EA Crespo. 2013. Living in an estuary: Commerson's dolphin (Cephalorhynchus commersonii (Lacépède, 1804)), habitat use and behavioural pattern. Latin American Journal of Aquatic Research 41(5): 985-991.

López CL \& D López. 1985. Killer whales (Orcinus orca) of Patagonia and their behavior of intentional stranding while hunting nearshore. Journal of Mammalogy 66: 181-183. 
MacLeod CD, L Mandleberg, C Schweder, SM Bannon \& GJ Pierce. 2008. A comparison of approaches for modelling the occurrence of marine animals. Hydrobiologia 612: 2132 .

Magris RA \& GF Déstro. 2010. Predictive modeling of suitable habitats for threatened marine invertebrates and implications for conservation assessment in Brazil. Brazilian Journal of Oceanography 58(4): 57-68.

Mann KH \& JRN Lazier. 1996. Dynamics of marine ecosystems. Biological-physical interactions in the oceans, 394 pp, Blackwell, Cambridge.

Mann J, RC Connor, LM Barre \& MR Heithaus. 2000. Female reproductive success in bottlenose dolphins (Tursiops sp.): life history, habitat, provisioning, and group-size effects. Behavioral Ecology 11: 210-219.

Miller PI \& S Christodoulou. 2014. Frequent locations of oceanic fronts as an indicator of pelagic diversity: application to marine protected areas and renewables. Marine Policy 45:318-329.

Mora C, DP Tittensor \& RA Myers. 2008. The completeness of taxonomic inventories for describing the global diversity and distribution of marine fishes. Proceedings of the Royal Society B: Biological Sciences B 275: 149-155.

Moura AE, N Sillero \& A Rodrigues. 2012. Common dolphin (Delphinus delphis) habitat preferences using data from two platforms of opportunity. Acta Oecologica 38: 24-32.

OBIS. 2014. Data from the Ocean Biogeographic Information System. Intergovernmental Oceanographic Commission of UNESCO. 〈http://www.iobis.org>.

Pearson RG, CJ Raxworthy, M Nakamura \& AT Peterson. 2007. Predicting species distributions from small numbers of occurrence records: a test case using cryptic geckos in Madagascar. Journal of Biogeography 34: 102-117.

Pedraza SN. 2008. Ecología poblacional de la tonina overa, Cephalorhynchus commersonii, (Lacépède, 1804) en el litoral patagónico. PhD Thesis, Universidad de Buenos Aires, Buenos Aires, 213 pp.

Phillips SJ \& M Dudik. 2008. Modeling of species distributions with Maxent: new extensions and a comprehensive evaluation. Ecography 31: 161-175.

Phillips SJ, RP Anderson \& RE Schapire. 2006. Maximum entropy modeling of species geographic distributions. Ecological Modelling 190: 231-259.

Phillips SJ, RP Anderson \& RE Schapire. 2004. A maximum entropy approach to species distribution modeling. In: Proceedings of the twenty-first international conference on Machine learning, Banff, Alberta, Canada, July 04-08, 2004, pp. 655-662.

Pineda E \& JM Lobo. 2012. The performance of range maps and species distribution models representing the geographic variation of species richness at different resolutions. Global Ecology and Biogeography 21: 935-944.
Praca E, A Gannier, K Das \& S Laran. 2009. Modelling the habitat suitability of cetaceans: Example of the sperm whale in the northwestern Mediterranean Sea. Deep-Sea Research I 56: 648-657.

Redfern JV, MC Ferguson, EA Becker, KD Hyrenbach, C Good, J Barlow, K Kaschner, MF Baumgartner, KA Forney, LT Ballance, P Fauchald, P Halpin, T Hamazaki, AJ Pershing, SS Qian, A Read, SB Reilly, L Torres \& F Werner. 2006. Techniques for cetacean-habitat modeling: a review. Marine Ecology Progress Series 310: 271-295.

Retana MV. 2013. Biogeografía de predadores tope en los golfos patagónicos. PhD Thesis, Universidad Nacional del Comahue, Bariloche, 118 pp.

Reyes LM. 2006. Cetacean distribution in the South Atlantic and South Pacific Ocean. Centro Nacional Patagónico (CENPAT), Consejo Nacional de Investigaciones Científicas y Técnicas (CONICET). 〈http://www.iobis.org>

Riccialdelli L, MA Torres, RNP Goodall, NA Dellabianca, LE Pimper, LM Reyes, A Fernández-Ajó \& R Bastida. 2011. Records of Risso's dolphin, Grampus griseus, in coastal waters of southern Argentina. Revista de Biología Marina y Oceanografía 46(3): 463-469.

Rivas AL. 2006. Quantitative estimation of the influence of surface thermal fronts over chlorophyll concentration at the Patagonian shelf. Journal of Marine Systems 63: 183-190.

Rivas AL \& JP Pisoni. 2010. Identification, characteristics and seasonal evolution of surface thermal fronts in the Argentinean Continental Shelf. Journal of Marine Systems 79: 134-143.

Roberts JJ, BD Best, L Mannocci, E Fujioka, PN Halpin, DL Palka, LP Garrison, KD Mullin, TVN Cole, CB Khan, WA McLellan, DA Pabst \& GG Lockhart. 2016. Habitat-based cetacean density models for the US Atlantic and Gulf of Mexico. Scientific Reports 6: 1-12.

Roux A, M Fernández \& C Bremec. 1995. Preliminary survey of the benthic communities of Patagonian shrimp fishing grounds in San Jorge Gulf (Argentina). Ciencias Marinas 21(3): 295-310

Rubín JP. 1997. La influencia de los procesos físico-químicos y biológicos en la composición y distribución del ictioplancton estival en el mar de Alborán y estrecho de Gibraltar. Informes Técnicos, Instituto Español de Oceanografía 24: 1-88.

Rubín JP, J Gil, J Ruiz, MD Cortés, F Jiménez-Gómez, M Parada \& J Rodríguez. 1992. La distribución ictioplanctónica y su relación con parámetros físicos, químicos y biológicos en el sector norte del Mar de Alborán, en julio de 1991 ('Ictio. Alborán 0791'). Informes Técnicos, Instituto Español de Oceanografía 139: 1-49.

Schiavini ACM, RNP Goodall, AK Lescrauwaet \& M Koen-Alonso. 1997. Food habits of the Peales dolphin Lagenorhynchus australis; review and new information. Reports of the International Whaling Commission 47: 827834 
Schiavini ACM, SN Pedraza, EA Crespo, R González \& SL Dans. 1999. The abundance of dusky dolphins (Lagenorhynchus obscurus) off north and central Patagonia, Argentina, in spring and a comparison with incidental catch in fisheries Results from a pilot survey in spring 1995. Marine Mammal Science 15(3): 828-840.

Sigler MF, KJ Kuletz, PH Ressler, NA Friday, CD Wilson \& AN Zerbini. 2012. Marine predators and persistent prey in the southeast Bering Sea. Deep-Sea Research II 65-70: 292-303.

Simpson JH \& JR Hunter. 1974. Fronts in the Irish Sea. Nature 250: 404-406.

Spear LB, LT Ballance \& DG Ainley. 2001. Response of seabirds to thermal boundaries in the tropical Pacific: the thermocline versus the Equatorial Front. Marine Ecology Progress Series 219: 275-289.

Svendsen GM. 2013. Distribución y uso de hábitat de mamíferos marinos en el golfo San Matías. PhD Thesis, Universidad Nacional del Comahue, Bariloche, 158 pp.

Svendsen GM, MA Romero, GN Williams, DA Gagliardini, EA Crespo, SL Dans \& RA González. 2015. Environmental niche overlap between common and dusky dolphins in North Patagonia, Argentina. PLoS ONE 10(6): e0126182. <https://doi.org/10.1371/journal.pone.0126182>

Sverdrup HU, MW Johnson \& RH Fleming. 1942. The oceans, their physics, chemistry and general biology, 1060 pp, Prentice-Hall, Englewood Cliffs.

Sydeman WJ, RD Brodeur, CB Grimes, AS Bychkov \& S Mc-Kinnell. 2006. Marine habitat 'hotspots' and their use by migratory species and top predators in the North Pacific Ocean: Introduction. Deep-Sea Research II 53: 247-249.

Tittensor DP, C Mora, W Jetz, HK Lotze, D Ricard, E Vanden Berghe \& B Worm. 2010. Global patterns and predictors of marine biodiversity across taxa. Nature 466: 1098-1101.

Tonini M, E Palma \& A Rivas. 2006. Modelo de alta resolución de los golfos patagónicos. Mecánica Computacional 25: 14411460 .

Torres LG, PE Rosel, C D'Agrosa \& AJ Read. 2003. Improving management of overlapping bottlenose dolphin ecotypes through spatial analysis and genetics. Marine Mammal Science 19: 502-514.

Torres LG, AJ Read \& P Halpin. 2008. Fine-scale habitat modelling of a top marine predator: do prey data improve predictive capacity? Ecological Applications 18(7): 17021717.
Tynan CT, DG Ainley, JA Barth, TJ Cowles, SD Pierce \& LB Spear. 2005. Cetacean distributions relative to ocean processes in the northern California Current System. DeepSea Research II 52: 145-167.

Varela S, RG Mateo, R García-Valdés \& F FernándezGonzález. 2014. Macroecología y ecoinformática: sesgos, errores y predicciones en el modelado de distribuciones. Ecosistemas 23(1): 46-53.

Viddi FA \& A-K Lescrauwaet. 2005. Insights on habitat selection and behavioural patterns of Peale's Dolphins (Lagenorhynchus australis) in the Strait of Magellan, Southern Chile. Aquatic Mammals 31(2): 176-183.

Viddi FA, R Hucke-Gaete, JP Torres-Florez \& S Ribeiro. 2010. Spatial and seasonal variability in cetacean distribution in the fjords of northern Patagonia, Chile. ICES Journal of Marine Science 67(5): 959-970.

Vila AR, C Campagna, M Iñíguez \& V Falabella. 2008. South American sea lions (Otaria flavescens) avoid killer whale (Orcinus orca) predation. Aquatic Mammals 34: 317 330 .

Wells RS \& KS Norris. 1994. The island habitat. In: Norris KS, B Würsig, RS Wells \& M Wursig (eds). The Hawaiian spinner dolphin, pp. 31-53. University of California Press, Berkeley.

Wells RS, AB Irvine \& MD Scott. 1980. The social ecology of inshore odontocetes. In: Herman LM (ed). Cetacean behavior: mechanisms and processes, pp. 263-317. Wiley, New York.

Whitehead H, B McGill \& B Worm. 2008. Diversity of deepwater cetaceans in relation to temperature: implications for ocean warming. Ecological Letters 11: 1198-1207.

Wisz MS, RJ Hijmans, J Li, AT Peterson, CH Graham \& A Guisan. 2008. Effects of sample size on the performance of species distribution models. Diversity and Distributions 14(5): 763-773.

Würsig B \& M Würsig. 1979. Behavior and ecology of the bottlenose dolphin, Tursiops truncatus, in the South Atlantic. Fishery Bulletin 77: 399-412.

Würsig B \& M Würsig. 1980. Behavior and ecology of the dusky dolphin, Lagenorhynchus obscurus, in the South Atlantic. Fishery Bulletin 77(4): 871-890. 